\title{
DISCOVERIES IN ASIA MINOR.
}

AT the commencement of our cruise along the south coast of Asia Minor we first touched at Capo Krio and examined closely the tombs in the neighbourhood of Cnidos, which were constructed on rising ground about two miles to the east of the ancient town. Most of them were about $20 \mathrm{ft}$. square; some built entirely of polygonal masonry, others with the sides in polygonal masonry and the fronts in square-cut stones. Along this front ran a narrow line of square-cut stones on which in most cases traces of inscriptions appeared, but owing to the nature of the stone almost all the letters were defaced with the exception of the following :

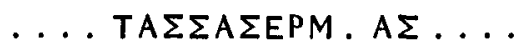

In the upper chambers were many grave altars and memorial tablets; in two graves we found altars with snakes represented as coiled around them, and in another an altar with the ordinary bull's head and garland decoration, bearing the inscription $O \triangle A M O \Sigma$ (ápé $\theta \eta \kappa \epsilon \nu$ ).

Proceeding along Capo Krio to the point where the land contracts into a narrow isthmus we found traces of other tombs which have lately been exposed to view by the washing away of the soil by a winter's flood. In these tombs have been found many small marble figures similar to those I found at Antiparos and described in this Journal (vol. v. p. 50). One represents a figure seated in a chair playing a harp similar to that in the Museum at Athens, which was found at Amorgos, another is of a female figure with a crescent on her head similar to one which I have seen, and which was discovered in the island of Tenos. These figures all bear a close resemblance to those found in the islands and serve as a further proof that the earlier inhabitants of the islands before the Hellenic occupation were, as Thucydides states, of Carian origin.

On leaving Capo Krio we visited the next promontory to the south, now known as Cape Alopeka. At the western extremity of this, round the bay of Aplotheka, are the ruins of the old town of Loryma, identified by an inscription and described by Schmidt in his Neue Lykische Studien. On bearing of extensive ruins three hours distant by land and one by sea, we rowed to the spot and entered a curiously hidden harbour across the entrance to which a stone could easily be thrown; about an hour's walk from this harbour are extensive ruins in a basin surrounded by lofty hills, and from 
a tombstone of the same character as those of Loryma, namely, massive monolithic pedestals cut in grades diminishing towards the summit, the highest of which was six feet, and all having a small hole or holes on the top as if they had carried a statue, we found that the place was in ancient times known as Kasarea, and taking Ptolemy as our guide we find that in his catalogue of Carian towns between Loryma and Phoenike he places K $\rho \hat{\eta} \sigma a$ $\lambda \iota \mu \eta \dot{v}$ (Lib. v. ch. 2). Now the modern village of Phoenike is about an hour's walk from here in an eastward direction and is built on the site of the old town: consequently the spot we were at coincided exactly with Ptolemy's $\mathrm{K} \rho \hat{\eta} \sigma a \lambda_{\iota} \mu \eta^{\prime} \nu$ and from the curious little harbour it appears obvious why it was thus designated. Pliny also mentions Portus Cressa as being just opposite Rhodes twenty miles distant (Lib. v. 29), hence there can be little doubt that this is the spot they allude to and was the ancient town and harbour of Kasarea. Round the base of a column built into a Byzantine church we found an inscription, which pointed to the fact that there had existed a temple of Apollo here.

Going eastwards in our ship we entered the Gulf of Makri and anchored amongst some islands to the north of the gulf, now known as Tarsinà, containing many traces of being extensively inhabited during the Byzantine period. The inhabitants told us of extensive ruins on the mainland opposite, and led us to a spot where the rock is honeycombed with tombs, most of them small irregular holes with slabs before them, but inaccessible unless one could have been let down by a rope from above. There were however some well executed rock-cut tombs similar to those found at Telmessus on the opposite side of the Gulf of Makri ; three of which I managed to reach.

One had an Ionic façade representing the front of a temple in Antis, with an inscription in red incised letters over the entrance : these letters appear to belong to no known alphabet, being a mixture of Lycian, Pamphylian and Greek characters. Other tombs represented the usual form of the Lycian cottage with projecting beams.

At a little distance from this spot we again landed and were conducted through a forest and over the brow of a hill and found ourselves amongst the ruins of an extensive city similarly situated to Kasarea, namely in a basin surrounded by hills; it would appear never to have had walls, but to have been protected by forts, and on the side where the isthmus on which it is built joins the mainland by a wall runving from the shore on one side to an inaccessible cliff on the other, one of these forts which commands the approach from the Gulf of Makri had before it two large domed tombs cut in the rock.

About two miles before reaching the ruins on a plateau overlooking the sea we found three large tombs, the foundation of a temple and other remains, and from two inscriptions here we gathered that the town in question was Lydae, the capital of a district called the Lydatis, and that the spot we were on was a deme of Lydae, called Arymaxis. The names given on the tombs were Roman, Caius Julius, and Heliodorus, members of the Diophantus family-names which occurled over and over again amongst the inscriptions 
we found at Lydae, as well as Boultinia, corresponding to the Roman gentile name Vultinia.

Amongst the most conspicuous of the remains in Lydae were two wellpreserved ruins of heroa, built above the town. One appears of a much earlier date than the other, and was built of very large well-cut stones. It had a domed roof and must have stood 50 feet high; it was approached by a flight of steps 22 feet long, and had columns of the Corinthian order on either side of this flight of steps and before the entrance. The width at the back was 27 feet 9 inches on the main wall, and 29 feet 7 inches at the base. The entrance at the front had been decorated with a deep cornice and the jambs also were richly carved; this fine doorway led into an upper chamber, 26 feet 7 inches long; running round three sides of it was a raised platform, on which apparently had stood sarcophagi-the fragments of one we found represented the labours of Hercules and was of good workmanship. Below this chamber and entered from below were four small chambers for tombs and the openings which led to them had been closed by sliding doors, 5 inches thick; the size of one chamber was 11 feet 9 inches by 7 feet, and each chamber contained the raised platform for sarcophagi as in the upper chamber.

The other heroon was of much inferior workmanship and obviously a Roman construction. In it we found fragments of several sarcophagi: one had on it three heads-evidently portraits-surrounded by garlands, supported by naked female figures at the centre, standing on small altars, and at the corners by draped female figures standing on the shoulders of kneeling old men; the back of this sarcophagus had bulls' heads below the garland, and on the sides heads of Medusa. From an inscription on this we gathered that it was the tomb of Caius Julius, the son of the man who built the tomb in the deme of Arymaxis. Another sarcophagus belonging to Coccias Sarpedonides was decorated by cupids holding bunches of grapes at which partridges were pecking. Outside this heroon on a frieze ran a long inscription, only the end of which was left: this frieze was supported by Corinthian capitals built into the wall; below, as in the other heroon, were four smaller chambers for tombs.

Down in the centre of the town we found many inscriptions all close together, on pedestals which had carried statues. This spot appears to have been the agora of Lydae, where complimentary monuments were erected. It will perhaps be as well to leave the inscriptions to tell their own story, but I will allude to a few which give us satisfactory dates concerning the proconsuls and praetors who ruled this district in the first century of our era.

One was erected to Sextus Marcius Priscus "praetor of the emperor Vespasian and of all the emperors from the time of Tiberius;" his name we again found two weeks later as having built a large bath at Patara. Two side by side were erected respectively to Mettius Modestus and C. Antius Quadratus, both mentioned by Waddington in his Fastes Asiatiques as proconsols in the time of Trajan. Quadratus appears to have been a native of Pergamos and to have held many posts in Asia Minor : he is alluded to in 
an inscription from the neighbouring Lycian town of Tlos with the title Boultinia added.

In the centre of the town we saw also three large heroa side by side similar in character to those above mentioned. Fragments of statuary lay around in every direction, and a hollow depression completely full of brambles was an obvious theatre, and on the hill-side opposite was another rock-cut tomb with an imitation beamed roof but having no inscription.

From the inscriptions we learnt that Lydae formed one of a decapolis of Lycian towns, that men of Lydae held from time to time places of high honour in the assemblies of the Lycian nation and in one or two cases where it was stated that the person in question had been citizen of these ten cities the Séka was carefully erased, pointing to the fact that harmony did not always exist in this decapolis. Inhabitants of Lydae took their wives from neighbouring cities Pinara, Telmessus, \&c., which cities are mentioned on their tombs. Also a doctor of Lydae, Aristobulus by name, would appear from the eulogistic inscription raised to his honour to have attained considerable renown in his profession.

The only allusion to this important Lycian city that $I$ can find is in Ptolemaius who mentions it in his list of Lycian towns in correct order, (Lib. 5, 28). "After Kaunos" he says "come Lydae, Carya, Daedala, Telmessus," taking the towns around the gulf of Makri in their correct order; by some curious mistake later geographers have placed Lydae on their maps as Chlydae, but the inscriptions which I have found now thoroughly establish both the name and the position.

Before leaving the Gulf of Makri we visited the site of other ruins, about five miles inland, and about double that distance from Lydæ. They consisted of an old Hellenic acropolis built on a rocky eminence overlooking a small lake, and now almost entirely surrounded by forest and brushwood, which made it impossible to ascertain the extent of the ruins, so that beside the fortress we were only able to find a few graves of simple construction formed out of huge blocks of stone; in these we found a few bronze remains, glass, and a small silver coin of Kaunos of the date of Lysimachus similar to a small copper one in the British Museum with the exception that that has not got the crux ansata.

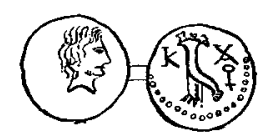

On the wall of the acropolis were two much defaced inscriptions on stones side by side, of the Ptolemaic age, and leading us to suppose that the name of the place was Lissa, or Lissae, though from Ptolemy's account it would appear as if this place was known in his time as Karya : there were traces of inscriptions on several other stones in the same line but too defaced to make out even a single word. It was with extreme difficulty that we 
obtained squeezes of the two partially legible ones owing to their height and the want of appliances in this wild spot.

Inasmuch as Pliny tells us that there were once seventy cities in Lycia, and in his time thirty-six, of which we only know the names of twenty-five, there is room for much more geographical discovery in this interesting district.

On our return voyage we stopped for a few days to examine the ruins of Patara, and were enabled to supplement the discoveries of former travellers by the addition of several inscriptions. The ruins of Patara will always present serious difficulties to the excavator, as the mouth of the old harbour, around which the principal buildings stood, has been silted up with sand, and the harbour is now represented by a large stagnant lake, and the ruins are principally situated in a spongy marsh; the theatre too, a magnificent structure of Roman date, is now nearly buried in sand. Close to the entrance to this, with considerable labour we turned over a huge stone $12 \frac{1}{2}$ feet long by 4 feet 10 inches, which had on it a large inscription in ten lines, in honour of one Polysperchon who had officiated as priest of the Patarean Apollo in the reign of Germanicus and held many important offices of state.

Several inscriptions allude to Patara as "the metropolis of Lycia" at that periud, and to the west of the harbour is a fine Roman palace, which appears to have been the residence of the Roman proconsul. Along the front of it runs an inscription which relates how it was built in the reign of an emperor whose name is obliterated, and on one side there is a stone let into the wall, having in relief upon it a fish holding a garland in its mouth and behind a trident.

At Patara there are two baths in excellent preservation, one of which from an inscription we learnt was built by the above-mentioned Sextus Marcius Priscus in the reign of Vespasian. The western side was 50 feet long, and the length must have been more than double; it had been richly decorated with columns and other ornamentations and was divided into five chambers opening into one another: over the entrance into the second was the inscription; the central chamber was rounded at each end, and each room was studded with holes in the wall, as if it had been covered with tiles or plaques, but from the fact that the inscription was itself studded with holes and partially covered with cement, it would appear that it had been used in Byzantine times on a new system. There were two vestibules to the east with wide spanning arches full of debris, and a careful excavation of this building would doubtless bring to light interesting facts concerning the construction of ancient bath-buildings.

Along the narrow end of the harbour, which runs about a mile and a half inland, the chief tombs of Patara were built; many of them handsome heroa, and many of a more humble structure. On one of these latter amongst some brambles we found an inscription which begins $\tau \grave{\eta} \nu \chi \epsilon \lambda \omega \nu \eta \nu \kappa a \tau \epsilon \sigma \kappa \epsilon \dot{v} a \sigma \epsilon \nu$, etc., proving that these tombs with rounded lids were called "tortoises" by the ancients.

In a wood about a mile from Patara was a rock-cut tomb entered 
originally by two stone panels : one of these was removed, but on the other were three coarsely draped figures and a late inscription, and on an adjoining pilaster cut in the stone were two hands outspread with the thumbs joining and on the palms distinctly-marked triangles; beneath these were the letters $\Omega \Delta|K A|$. .

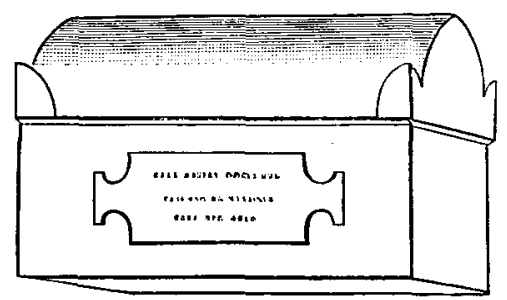

Our ship lay at anchor in the harbour of Phournoi some six miles from Patara, and almost the whole length of this walk we performed each day on the remains of the Roman aqueduct, the ruins of which at the entrance to the town is one of the most conspicuous objects in the place. About five miles from Patara this aqueduct crosses a col with a structure a quarter of a mile long built of large polygonal stones, and below it is pierced by two gateways of irregular form.

J. Theodore Bent. 